\title{
Municipal Management and Strategies against the COVID - 19, District Banda Shilcayo - San Martin Peru, 2020
}

\author{
Bardales JMD* and Davila KS \\ National University of San Martín, Peru
}

*Corresponding author: José Manuel Delgado Bardales, National University of San Martín, Peru, Email: jmdelgado@unsm.edu.pe; ORCID no: 0000-0001-6574-2759

\section{Opinion \\ Volume 6 Issue 2}

Received Date: April 12, 2021

Published Date: April 26, 2021

DOI: $10.23880 /$ oajmb-16000192

\section{Opinion}

In Latin America, the first contagion of COVID-19 was identified in Brazil, coming from Europe, Italy. In addition, the first time that the coronavirus spread in the US was recorded and as well the appearance of the virus was detected in Mexico. On February 29, 2020, it appeared in Ecuador and the first death in the US because of the virus was confirmed. Subsequently, the declaration of emergency was given in Washington, on March 1, 2020, to which Florida was added. Five states joined during next days, including New York. On March 3, 2020, Argentina and Chile reported the first case. Chronologically, the appearance of Covid-19, considered a pandemic that affects Peru according to Radio Programs of Peru (2020), was reported at the end of 2019 and the first days of January 2020, with 44 patients with pneumonia reported in Wuhan, China. On March 5, 2020, Peru reported the first infection with the virus, being a 25 -year-old male with respiratory disease who traveled through different cities in Europe 14 days before the onset of symptoms.

This research aimed to establish the relationship with municipal management strategies against the Covid-19 in the district La Banda de Shilcayo, 2020. The research was basic and has a non-experimental descriptive and correlational design. The population and sample were 18 executives from this office. The used technique was the survey and the questionnaire as an instrument. Among the results, the municipal management of the municipality of La Banda de Shilcayo stands out with a "regular" level of $39 \%$, and the implementation of the strategies against Covid-19 shows a "regular" level with 50\%.

A comparison to Bautista's findings (2016) arises a point of reference, in view of the role of local government in the quality of health from planning to managing supplier and quality control. A plan of quality management must be implemented before the new care plan. It is important to have a baseline with details of the health conditions and on that basis to make projections to define activities, which are responsible and deliverable, according to the closing time of gaps. Mego [1], 54\% of users were located in downtown area, with urbanization, new human settlements and other human settlements often test the quality services provided by the Provincial Government of Chiclayo, so we can infer that it is not only important to offer the service, but the quality service and how to offer it must be considered, in order to satisfy the demand of the citizens and meet the expectations. Flores [2], refers that the municipal management of La Banda de Shilcayo, has a "good" average of $32.6 \%$, that study shows similarity with the finding in the study, showing a "good" level of $27 \%$, where both refer that the management has adequate actions and works based on planning.

Hurtado predicts the situation in Peru: only 49.95\% of municipalities have institutional operating plans (POI), which makes it difficult to clarify planning through the budget allocation that tests municipal efficiency, in response to the problems of the people. When contrasting to the study, it differs significantly; because the studied municipality prioritizes planning and coordination so they can detach actions for the well-being of the citizens. Carroz noted that the impact of the crisis during this management is mainly due to national policies which are inconsistent with the development of strategic capabilities, according to this it is inferred that in order to create the conditions, all this has to be grounded in politicians decision and the technical part, where the articulation can be created and also linked 


\section{Open Access Journal of Microbiology \& Biotechnology}

various actors with the single purpose that is the well-being of the population. Ávila in their research concluded those two weeks after the first case of influenza An in Peru the epidemic began, the migrant population under investigation did not have enough knowledge.

Diseases and preventive measures are often not implemented. This showed finding generates similarity to the study because it can be inferred that despite having implemented actions and strategies to tackle the disease were insufficient because the preventive part generated by the health sector has not been the most relevant to cope with the pandemic and this is complemented by the behavior of the population. Ruiz [3], shows a Pearson coefficient of 0.937, which indicates the alignment between the established variables, and at the same time explaining that $87.9 \%$ of the fulfillment of goal 4 is influenced by the municipal management, this result is associated with management, which is decisive for the best actions of the commune. The study has similar correlation results, where management has potential influence on the other intervening variables [4-8].

\section{Conclusion}

There is a high positive relationship between municipal management and strategies against Covid-19 in the District Municipality of La Banda de Shilcayo, 2020, supported by a Pearson coefficient of 0.922 . Likewise, a coefficient of determination of $(0.849)$ explaining that $84.9 \%$ of the implementation of strategies against COVID -19 is influenced by municipal management. Therefore, the municipal authority must promote horizontal municipal management with the active participation of the Municipal Council and its executives, in order to articulate concrete actions and respond efficiently to the demand of the community, as well as in order to achieve tangible products and results that benefit citizens, thereby achieving the generation of public value.

\section{References}

1. Mego NO (2011) Proposal for a quality management system to improve the service in the provincial municipality of chiclayo, lambayeque. Red de Repositorios Latinoamericanos.

2. Flores B (2019) Municipal Institutional Management and its relationship with tax incentives, in the district of La Banda de Shilcayo, 2018. Tarapoto - Peru: Universidad César Vallejo.

3. Ruiz TE (2020) Relationship of municipal management with the fulfillment of goal 4 in the district municipality of La Banda de Shilcayo, 2019. Tarapoto - Peru: Universidad César Vallejo.

4. Lemma M (2017) Urban management and urban planning in Córdoba, Argentina. Urbe Rev Bras Gest Urbana 9(3): 474-486.

5. Calleros HP, Abarca AP (2018) Evidence for the diagnosis and treatment of influence in adults. Atencion Familiar 25(3): 118-122.

6. (2020) Coronavirus: Esta es la cronología del COVID-19 en el Perú y el mundo. rpp.pe.

7. Quispe T, Evaristo J (2020) Accountability in the management of the municipal government of Puno-Peru (2011-2018). Communication 11(1): 63-76.

8. Saavedra MJV, Fernández L, Quiroz J, Revilla AC (2020) Municipal management and response to the impact of Covid-19 municipalities of the upper andin area, department of Lambayeque. Pakamuros 8(4): 105-115. 